\title{
TV/Series
}

19 | 2021

Perfectionnisme et séries télévisées. Hommage à Stanley Cavell (1926-2018)

\section{The Value of Cities of Words. Cavell on Perfectionism, Films, and TV Series}

\section{Paola Marrati}

\section{(2) OpenEdition}

\section{Journals}

Electronic version

URL: https://journals.openedition.org/tvseries/5060

DOI: $10.4000 /$ tvseries.5060

ISSN: 2266-0909

Publisher

GRIC - Groupe de recherche Identités et Cultures

\section{Electronic reference}

Paola Marrati, "The Value of Cities of Words. Cavell on Perfectionism, Films, and TV Series", TV/Series [Online], 19 | 2021, Online since 06 May 2021, connection on 14 May 2021. URL: http:// journals.openedition.org/tvseries/5060 ; DOl: https://doi.org/10.4000/tvseries.5060

This text was automatically generated on 14 May 2021.

\section{cc) (†)}

TV/Series est mis à disposition selon les termes de la licence Creative Commons Attribution - Pas d'Utilisation Commerciale - Pas de Modification 4.0 International. 


\title{
The Value of Cities of Words. Cavell on Perfectionism, Films, and TV Series
}

\author{
Paola Marrati
}

\section{Introduction: Cavell, the perfectionist aspect of philosophy and the future of democracy}

1 At the center of Cavell's attempt to renew, and to a certain extent redefine, the tradition of moral perfectionism lies his conviction that perfectionist attitudes are both constitutive of one aspect of philosophy, the one (that is) turned toward the knowledge of the self, and necessary for the survival of democratic societies. His work on Hollywood comedies and melodramas speaks directly to how intertwined personal change and democratic aspirations are in his view and to the philosophical and pedagogical value he credits popular films with. I believe, with many others, that contemporary TV series deserve the same serious philosophical attention that films have received and I also believe, with some others, that Cavell's ideas about what binds perfectionist quests for personal change and democracy remain not only valid but crucial in our contemporary cultural and political landscape.

2 And yet there are so many reasons to doubt whether philosophy may be of any use for the moral improvement of humans (ourselves included), let alone contribute to achieve a little more social justice or help defend the very fabric of democratic societies which seems more fragile today then even a few years back. Certainly we no longer have Plato's conviction that philosophy can discover the form of the ideal city and philosophers are meant to be its faithful guardians (which is a good thing in my opinion). True, some remain committed to Marx's reversal of the task of philosophy from that of interpreting the world to the one of transforming it. But Marx's revolutionary hopes - for philosophy and for the world - are already an admission that philosophy can at best be part of a transformation that largely exceeds it, that is to say 
that philosophy alone can do very little. The same holds true, it seems to me, for most philosophers who, contrary to Plato and Marx, have an explicit commitment to democracy.

3 For those of us who care about the world we live in and its future, it is difficult not to feel helpless at times both as citizens - which is bad enough - and as people who study and teach philosophy for a living. While the human sciences in general may not be deemed particularly important either, and their transformative power in the moral and political domains is equally doubtful, they at least have a recognizable purpose and produce some recognizable knowledge whereas philosophy seems - at times or in a certain mood -uniquely aimless, not only without any practical use but also with little if any theoretical value, achieving nothing that fits accepted standards of what counts as knowledge (unless of course it turns to logic or some version of the cognitive sciences to claim legitimacy).

4 Stanley Cavell was, I believe, deeply aware of how vulnerable philosophy is, and in a sense should be, to old and new accusations of being nothing but idle talk as well as of the danger for philosophy to become indeed little more than idle talk, its professionalization notwithstanding. These dangers, and this vulnerability, do not come from the outside - the indifference or hostility of culture at large, the changes in the structure of higher education and the like -, but more crucially from the very nature and practice of philosophy itself. For if philosophy produces knowledge, it is a kind of knowledge with no stable content nor generalizable methods, with no authority and uncertain outcomes. And if philosophy needs to be learnt and taught, like any other discipline, exactly how and what one learns or teaches remains largely unpredictable. And yet, for Cavell, we do need philosophy not in spite but precisely because of the peculiar kind of knowledge it offers or searches for. Such a need might not be felt by everyone, and certainly no one feels it all the time but it exists, it is real, and is what gives philosophy its audience: inside and outside of academia. How convincing Cavell's idea that there is an audience for philosophy is depends largely, of course, on his understanding of what philosophical knowledge is about.

\section{From Cities of Words to two kinds of knowledge}

Cities of Words is an exemplary text in this regard: it offers one of Cavell's most explicit accounts of what connects philosophy - in its disciplinary recognized and recognizable sense - to perfectionism understood not as a moral doctrine but as a register of the moral life (which is quite a different matter) and to films. What is at stake in bringing together instances of philosophy and instances of film from the perspective of moral education is precisely to examine in concrete cases what kind of knowledge philosophy is, how and why it matters outside of its academic domain narrowly construed; to show how and why philosophy is sometime called for in our individual and collective lives.

6 Certainly this set of problems and connections is not unique to Cities of Words, versions of (variations) such questions are everywhere to be found in Cavell's work, they are a constant preoccupation of his philosophy, but a remark he makes in Cities of Words has always impressed me because in its very simplicity captures so much of what is at stake:

[Well, as Freud says,] there is knowledge and there is knowledge. And there is also such as thing as a culture's knowing something together, knowing something at the 
same time the others know, knowing that each knows, knowing as first person plural (something the word consciousness should suggest), a knowledge that the culture has of itself. I think of it as knowledge that we have of, let us say, the path the culture is - we are - making for itself, as if it were unconsciously, something that philosophy is in a position to articulate and so bring to consciousness in its way. Philosophers from Plato to Hegel and Emerson and Nietzsche and Heidegger, and in a sense Wittgenstein, have taken this as an essential mission of, or call upon, philosophy. (It requires statistics to know how many of our fellow citizen, those who speak for us and for whom we speak, live in poverty. It requires something else to articulate what our attitudes to the poor are, and to imagine how this plural attitude can be voiced with confidence ${ }^{1}$.

It is uncontroversial (one may hope) that statistics, that is to say a form of positive knowledge, is necessary to assess the level of poverty at any given time and place; it is also fairly unproblematic to notice that "something else" is needed to articulate to oneself and to one another where we stand, as a society, toward poverty (or climate change, immigration, gender equality etc.): that is after all what democracy is, or should be, about.

What is neither uncontroversial nor unproblematic, however, is that for Cavell this "something else" that is needed is itself a form of knowledge and not just a matter of opinions, habits of thought, beliefs (religious or otherwise), real or imagined interests, ideology and the like. In other terms, Cavell wants to frame the difference at stake here not in terms of the distinction between knowledge and opinion, as we might expect, but in terms of different forms of knowledge. But what are these two different kinds of knowledge? Or, why call knowledge the need to articulate for one another where we stand?

9 The first kind of knowledge, of which statistics is a good example, is relatively easy to define. It refers to any form of scientific or disciplinary knowledge, to the study of specific objects and fields, established with specific methods of research and learned in specific ways (mathematics, economy, sociology, engineering, history or literature all fit the bill - the list is not exhaustive of course; even philosophy, in the professionalized sense of the term, might on occasion fit the bill). It is the conception of knowledge traditionally associated with Enlightenment, with the faith in the power of reason to disperse the darkness not only of ignorance, but also of prejudice, foolishness and superstition that grow unchallenged in its shadows and to guide humans toward personal and political autonomy. Such a faith in reason remains, I believe, an important part of our explicit or implicit commitment to democracy. After all, the autonomous individual, capable of making her own informed decisions Kant calls for in what is Enlightenment?, is the ideal democrat we all want our fellow citizens to be or to become (assuming of course we ourselves are already enlightened enough). Who could possibly want an ignorant, foolish, prejudiced public opinion wield unchecked power?

The second kind of knowledge Cavell talks about and associates with philosophy, or some versions of it, however is more difficult to define. What are we supposed to understand by "knowing together"? How can we do it? And who are "we" who are called upon to know together? What vision of philosophy, and of reason, sustains such demands? In a passage from the Forward to Must We Mean What We Say Cavell reclaims the Socratic origins and lasting aspiration of philosophy and brings us directly at the heart of the matter:

When Socrates learned that the Oracle had said no man is wiser than Socrates, he interpreted this to mean, we are told, that he knew he did not know. And we are 
likely to take this as a bit of faded irony or as a stuffy humility. What I take Socrates to have seen is that, about the questions which were causing him wonder and hope and confusion and pain, he knew that he did not know what no man can know, and that any man could learn what he wanted to learn. No man is in any better position for knowing it than any other man - unless wanting to know is a special position. And this discovery about himself is the same as the discovery of philosophy, when it is the effort to find answers, and permit questions, which nobody knows the way to nor the answer to any better than yourself. Then what makes it relevant to know, worth knowing? But relevance and worth may not be the point. The effort is irrelevant and worthless until it becomes necessary to you to know such things. There is an audience for philosophy².

Socrates's discovery is the discovery of a domain of questions and problems he is not free to ignore because they bring him joy and pain, hope and despair, and these are problems and questions that cannot find answers in any established body of disciplinary knowledge, but only in the examination of the self and in the dialogue with those who feel them with same urgency and necessity. Not everyone experiences the power of such questions or comes under the grip of such problems, and no one feels it all the time, but when these dialogues take place no voice has more authority than any other. It is, I believe, what Cavell calls "conversation" which is simultaneously a description of the practice of philosophy and a necessity for the life of democracy. The discovery of such a domain of knowledge where all questions are permitted and no one is in a better position to know than anyone else is the discovery of philosophy itself and explains the peculiar nature of philosophical knowledge which is both ungrounded (in any authority) and necessary.

\title{
2. The two pictures of reason in American philosophy: Cavell about Dewey and Emerson
}

12 The importance of distinguishing these two registers of knowledge for thinking in general, and for thinking about democracy in particular appears clearly in Cavell's characterization of the differences between Emerson's and Dewey's views on these matters. In his essay significantly entitled What's the Use of Calling Emerson a Pragmatist? Cavell writes:

\begin{abstract}
Dewey seeks to address a situation of unintelligence, which I suppose is to say one that negates whatever predicates of intelligence a philosopher holds dearest, hence a situation that variously manifests superstition, bigotry, gullibility, and incuriousness. In a similar vein Emerson discerns a scene of what he variously calls conformity, timidity, and shame, something he describes as secret melancholy. It is a condition Thoreau will more famously name quiet desperation, which Thoreau perceives to characterize the lives of the mass of men. The connection between massive unintelligence and general despair is that both are barriers to the future, to the new day whose appearance both Emerson and Dewey, in their ways, would hasten. But the ways are as different as the accompanying ideas of the future; they amount to different ideas of thinking, or reason. I once characterized the difference between Dewey and Emerson by saying that Dewey wanted to get the Enlightenment to happen in America, whereas Emerson was in the later business of addressing the costs of the way in which it has happened ${ }^{3}$.
\end{abstract}

These two pictures of reason or thinking offer different pictures of what threatens democracy: I don't think we should choose, or that Cavell thought we had to. It seems to me they both remain valid and their tension productive in emphasizing different 
kinds of challenges that it would be equally dangerous to simply ignore. In other terms, if Cavell gives so much attention to Emerson, it is not because he considers that "superstition, bigotry, gullibility, and incuriousness" have disappeared from the face of the earth, but rather because he strongly believes that the condition Emerson and Thoreau describe is more pervasive than ever while the awareness of such a condition remains concealed or repressed.

This said, the fact remains that these two pictures of reason put a very different emphasis on what kind of knowledge we need to cultivate, what our priorities should be when it comes to counter what threatens democracy and prevents it from achieving a better future or living up to its promise. Dewey's remedy for the condition of "massive unintelligence" he perceives is, as we know, to advance and reform education. Only by learning, and learning better, we can hope to solve the problems society faces as well as improve our lives, develop our creativity and enjoy the arts. If the system of education itself is in need of reform and a new pedagogy is badly called for, what we need to learn remains for Dewey - traditionally enough - the "arts and sciences".

But if our condition is one of "general despair," how can it be countered? Scientific and humanistic knowledge, valuable as they undoubtedly are, cannot help overcome a melancholy that does not find its origins in ignorance or insufficient capacity for critical thinking but instead in "conformity, timidity, and shame." What makes us despair - quietly - of democracy in this Emersonian and Cavellian picture is less the magnitude of the problems our society faces and the injustice it tolerates or produces than our incapacity to address them. Such incapacity is not due to the lack of intelligent solutions, creative thinking or scientific advances -and in this sense has no justifications, no reasons -, but is due rather to our personal and collective indifference, inaction, silent resignation, conformity, or withdrawal. We may well feel shame toward the present state of our society, but shame alone has no redeeming qualities: it is more likely to bring to despair than to change.

\section{Democratic promise, perfectionist education and cinema}

But if "despair" is indeed a widespread condition that voids democracy of its promise and of its capacity for change and transformation (and we may of course disagree with such a diagnosis), one may wonder why Cavell insists so strongly on the political importance of perfectionism and moral education in general and on the democratic value of certain films and aspects of popular culture in particular ${ }^{4}$. What do we learn, and what do we learn together, in watching a film or a TV series that can help counter (political) despair? Things we are increasingly likely to do, it should be also noticed, alone in front of a computer screen.

17 I gladly admit that the only reasonable answer to such questions when put so bluntly seems to be: nothing much. Certainly nothing that belongs to the first register of knowledge we have discussed. And certainly nothing that bears a straightforward relation to moral and or political change. But the fact is that there are no straightforward ways to transform oneself or our society, no methods to guide us on the path toward change (the enormous amount of literature on "self-improvement" notwithstanding). As well as there are no singular paths and pre-established visions of 
what change should look like because if there were such things - reliable methods, secure paths, unambiguous concepts of justice - it would mean that we already know what we need to become, what virtues to cultivate, how much injustice is reasonable to tolerate, whose voices deserve to be listened to, what suffering is, whose suffering counts, and whose pain comes first. Do animals have a voice in the conversation of justice? Are those who do not hear their pain simply deaf or "soul-blind"? How does it come then that one and the same person may endlessly hesitate between compassion and indifference?

For Cavell, and this important, we do not know such things, at least we do not know them once and for all and with certainty; as we do not know, once and for all and with certainty, what we truly need or desire. We do not know such things either alone or together, and this is why philosophy as conversation is at times called for: not to provide definitive answers, but to allow our uncertainties, dissatisfactions, unacknowledged desires to be voiced and taken seriously.

It is not by chance that the films Cavell loves are all examples of singular journeys, encounters, and discoveries. They are instances of the difficult search of the knowledge of oneself and the acknowledgment of others, of how challenging the acceptance of existence actually is. What they teach, if or when we are capable to learn, is simply that existence - of the world, of ourselves, and of others - is at issue in ordinary life as much as in abstract and obscure philosophy. And that avoidance, common as it is, always comes at a price. They also teach that this kind of knowledge may be called for in the most different situations and may occasion unforeseeable answers. If some films have value for a perfectionist education, as for Cavell they certainly do, we shouldn't imagine that such value can be cashed out in any straightforward manner: as well as moral perfectionism does not offer a list of moral norms, a perfectionist education does not produce measurable results, what we learn remains open and unpredictable. ${ }^{5} \mathrm{I}$ believe the same holds true for TV series or for some TV series: those that have perfectionist moments and invite perfectionist conversations.

Some of the films in Cavell's canon, not all, let us imagine happy endings. I must confess that to me these are the ones that matter more and I would like on this occasion to express my immense gratitude to Stanley Cavell for, among so many things, having given me the courage to admit it openly (and to myself in the first place). His insistence on the private and public value of "pursuits of happiness" (in the book with the same title and elsewhere), so out of sync with most of our dominant intellectual debates and so seemingly but falsely close to a pervasive culture of "entertainment," is not simply a reminder that happiness, like all emotions, has a political dimension, which is important enough, but also crucially that happiness is much more difficult to pursue let alone cultivate than fear, resentment, hate, or disillusionment (despair). And in a certain sense, I would like to suggest, the difficulty of the pursuit of happiness is one aspect of the difficulty of democracy which can hardly survive without faith in the possibility of change in spite of its scene of constant disappointment.

\section{From The West Wing to Cavell}

But even if one accepts Cavell's ideas about the significance of pursuits of happiness for the life of democratic societies, the fact remains that the value of films and TV series in this regard is not obvious to say the least. What relation can there possibly be between 
watching a (very satisfying) remarriage comedy and finding my way back into my marriage, let alone into my society?

In an attempt to answer such legitimate questions I would like to take an example outside of Cavell's canon, namely The West Wing (NBC, 1999-2006) by Aaron Sorkin. It is clearly an idealized picture of democracy, or more precisely of the democratic exercise of government. I know as anyone else that this is not how real administrations, not even the best ones, work. In The West Wing the moral and political disagreements may be intractable, there never is one answer that is simply right, or the only right one; sometime everyone is wrong and sometime there is no right thing to do at all; sometime the constraints of reality win over the most committed efforts to change and the limits of agency and good intentions are painfully shown. Friendships and loves are tested, sometime beyond repair. And what is achieved, at the end, is very little of what was hoped for. But in the dialogues the meaning of words in never belittled and the desire to make oneself intelligible, even when it fails, is never negated. Of course I know that this precisely the most idealized aspect of The West Wing and the reason why it is such a perfect example of a "city of words".

And yet I remain convinced that I have learned something watching this show, and others may have too, that it is significant and should not be simply discounted as entertainment or, worse, as pernicious ideology even if it is nothing more, and does not claim to be anything more, than a "city of words." So the question becomes, what is the value of mere cities of words? Do they really matter? Why do we care (when we do)? Cavell, in a discussion of Emerson's trust in a possible audience for his writings, openly addresses the question of what value, if any, the imagination of "cities of words" has:

[So my question becomes:] Is there some conceivable political importance for an invisible group whose size is unknowable and whose composition is undeclarable? One way for me to answer, or to keep the question alive, is to say that it is important if Socrates's idea of a "city of words" is important. Which is to claim that if, as I suppose, this imagined city of perfect justice, in whose public affairs alone Plato's Socrates imagines the philosopher can participate, is realized by the text called Plato's Republic, then a democratic successor of it, as it were, is the Emersonian essay. A drastic difference is that imagining the perfected democratic city does not exempt us from acting in the present scene of imperfection [...]. On the contrary, this imagining is what enables us to act, that is, to exist in freedom from a despair of democracy; there is no one other than the likes of us either to act within the present city or to imagine its difference from itself. It is a freedom that depends on not letting others tell us - not the closest friend - whether our actions, of mind and body, are successful or not, whether they are "worth the candle" or not $^{7}$.

\section{Conclusion}

The value of imagining (my) ideal city of words does not consist in knowing that it is not the city I live in (no imagination is needed for that); nor in the model if offers of what the just city should be (projecting justice in the unreachable realm of ideas and ideals does not necessarily free me from despair), but its value consists rather in my affirming "this is how I would like it to be." It is an expression of what John Stuart Mill calls the rights of desires, an affirmation of the desirability of the world, one I hope to share with some known, and some unknown, others. 
course, one can always legitimately ask what distinguishes the desirability of the world from sheer escape in fantasy, narcissism, ideology, or some version of "cruel optimism ${ }^{8}$." Maybe nothing, certainly nothing tangible: there is always the possibility that the one may turn to be the other (or a debased version of the other). And yet, for those who experience the truth of skepticism, that is to say that existence cannot be proved or justified but only accepted, the desirability of the world - ungrounded as it is - offers some help in countering despair.

\section{BIBLIOGRAPHY}

BERLANT, Lauren, Cruel Optimism, Durham, Duke University Press, 2011.

CAVELL, Stanley, The Claim of Reason: Wittgenstein, Skepticism, Morality, and Tragedy [1 $1^{\text {st }}$ ed.: 1979], Oxford, Oxford University Press, 1999.

CAVELl, Stanley, Must We Mean What We Say [1 $1^{\text {st }}$ ed.: 1969], Cambridge, Cambridge University Press, 2002 .

CAVELL, Stanley, "What is the Emersonian Event? A comment on Kateb's Emerson" [1 $1^{\text {st }}$ ed.: 1994], in Emerson's Transcendental Etudes, Stanford, Stanford University Press, 2003, p. 183-191.

CAVELL, Stanley, “What is the Use of Calling Emerson a Pragmatist?" [1 ${ }^{\text {st }}$ ed.: 1996], in Emerson's Transcendental Etudes, ibid., p. 215-223.

CAVELL, Stanley, Cities of Words: Pedagogical Letters on a Register of the Moral Life, Cambridge, Harvard University Press, 2004.

LAUGIER, Sandra, “Popular Cultures, Ordinary Criticism: A Philosophy of Minor Genres”, trans. into English by Daniela GINSBURG, in Philosophy and New American TV Series, eds. Paola MARRATI and Martin SHUSTER, MLN (Comparative Literature Issue), vol. 127 n 5, December 2012, p. 997-2012. LAUGIER, Sandra, Nos vies en séries. Philosophie et morale d'une culture populaire, Paris, ClimatsFlammarion, 2019.

SAITO, Naoko, The Gleam of Light: Moral Perfectionism and Education in Dewey and Emerson [1 $1^{\text {st }}$ ed.: 2005], foreword by Stanley CAVELL, New York, Fordham University Press, 2018.

\section{NOTES}

1. Stanley Cavell, Cities of Words: Pedagogical Letters on a Register of the Moral Life, Cambridge, Harvard University Press, 2004, p. 83.

2. Stanley Cavell, Must We Mean What We Say [1 ${ }^{\text {st }}$ ed.: 1969], Cambridge, Cambridge University Press, 2002, p. XLII.

3. Stanley Cavell, "What is the Use of Calling Emerson a Pragmatist?" [1 $1^{\text {st }}$ ed.: 1996], in Emerson's Transcendental Etudes, Stanford, Stanford University Press, 2003, p. 222. On the relation between Dewey and Emerson from a Cavellian perspective, see Naoko Saito, The Gleam of Light: Moral 
Perfectionism and Education in Dewey and Emerson [ $1^{\text {st }}$ ed.: 2005], foreword by Stanley Cavell, New York, Fordham University Press, 2018.

4. On Cavell and popular culture, see in particular Sandra Laugier, Nos vies en séries. Philosophie et morale d'une culture populaire, Paris, Climats-Flammarion, 2019, and "Popular Cultures, Ordinary Criticism: A Philosophy of Minor Genres", in Philosophy and New American TV Series, eds. Paola Marrati and Martin Shuster, MLN (Comparative Literature Issue), vol. $127 \mathrm{n}^{\circ}$ 5, December 2012, p. 997-2012.

5. For Cavell, the relation between teaching and learning, embedded as it is in the intimate connections of words and life, is never a simple one. As he writes in the Claim of Reason: "Of course the person, growing, will learn other things about those concepts and "objects" also. They will grow gradually as the child's world grows. But all he or she knows about them is what he or she has learned, and all they have learned will be part of what they are. And what will the day be like when the person "realizes" what he "believed" about what love and trust are authority are? And how will he stop believing it? What we learn is not just what we have studied; and what we have been taught is not just what we were intended to learn. What we have in our memories is not just what we have memorized.", The Claim of Reason: Wittgenstein, Skepticism, Morality, and Tragedy [1 $1^{\text {st }}$ ed.: 1979], Oxford, Oxford University Press, 1999, p. 177.

6. It would be interesting to discuss in some detail the relation of The West Wing to more recent TV shows like Madam Secretary by Barbara Hall (CBS, 2014-2019) and Scandal by Shonda Rhimes (ABC, 2012-2018), that also deal with the inner life of the White House and its occupants. From the perspective of Cavell's moral perfectionism, which is the one considered here, it seems to me that Madam Secretary reclaims many aspects of The West Wing - with the significant and welcomed difference of casting a woman as the main character - whereas Scandal strikes, in my view, a quite non-perfectionist tone. The commitment all the main characters express at some time or another to the "Republic" (rather than to democracy) is highly emblematic of the fact that what they have in common, and value the most, is a privileged access to a kind of knowledge (and power) that neither can nor should be shared with everyone else. Their knowledge sets them apart, in principle and in fact, from everyone else; it is the source of their authority and power and the exact opposite of that dimension of "knowing together" Cavell takes to be philosophy and democracy's true ambition and aspiration.

7. Stanley Cavell, "What is the Emersonian Event? A comment on Kateb's Emerson" [1 ${ }^{\text {st }}$ ed.: 1994], in Emerson's Transcendental Etudes, op. cit., p. 189-190 [p. 183-191)

8. See Lauren Berlant, Cruel Optimism, Durham, Duke University Press, 2011.

\section{ABSTRACTS}

This essay is inspired by Stanley Cavell's attempt to renew, and to a certain extent redefine, the tradition of moral perfectionism lies his conviction that perfectionist attitudes are both constitutive of one aspect of philosophy, the one (that is) turned toward the knowledge of the self, and necessary for the survival of democratic societies. His work on Hollywood comedies and melodramas speaks directly to how intertwined personal change and democratic aspirations are in his view and to the philosophical and pedagogical value he credits popular films with. The claim of the essay is that contemporary TV series deserve the same philosophical attention that films have received and, subsequently, that Cavell's ideas about what binds perfectionist quests 
for personal change and democracy are crucial in the present cultural and political landscape. The West Wing series is taken as an example.

Cet article s'inspire de la tentative de Stanley Cavell de renouveler, et dans une certaine mesure de redéfinir, le perfectionnisme moral ; pour Cavell les attitudes perfectionnistes sont constitutives d'un aspect de la philosophie, tourné vers la connaissance de soi, et sont nécessaires à la survie des sociétés démocratiques. Ses études sur les comédies et les mélodrames hollywoodiens témoignent directement de l'inséparabilité du changement individuel et des aspirations démocratiques, ainsi que de la valeur philosophique et pédagogique des films de Hollywood. La thèse de l'auteure est que les séries télévisées contemporaines méritent la même attention philosophique que les films et, par conséquent, que la vision par Cavell de la quête perfectionniste de changement et de la démocratie est cruciale dans le paysage culturel et politique aujourd'hui. La série Á la Maison-Blanche (The West Wing) est prise comme exemple.

\section{INDEX}

Keywords: Cities of Words, conceptions of philosophy, democracy, education, The West Wing Mots-clés: À la Maison-Blanche, conceptions de la philosophie, démocratie, éducation, Philosophie des salles obscures

\section{AUTHOR}

\section{PAOLA MARRATI}

Paola Marrati is a professor at Johns Hopkins University in Baltimore (MD) since 2003 where she teaches modern and contemporary French philosophy. She was Program Director at the International College of Philosophy (ICPh) from 2001 to 2007. Prior to teaching in the United States, Paola Marrati held a chair in philosophy of art and culture at the University of Amsterdam. Her research interests include contemporary French philosophy, in particular Jacques Derrida and Gilles Deleuze, American philosophy, in particular the moral and political issues in Cavell's philosophy, film studies and gender studies. He is the author of, among others: La Genèse et la Trace. Derrida lecteur de Husserl et Heidegger (Kluwer, 1998), Gilles Deleuze, cinéma et philosophie (PUF, 2003) and Gilles Deleuze. Cinema and Philosophy (Johns Hopkins University Press, 2008). She edited Understanding Cavell, Understanding Modernism (Bloomsbury Press, forthcoming in December 2021).

Paola Marrati est depuis 2003 professeure à l'Université Johns Hopkins de Baltimore (Maryland) où elle enseigne la philosophie française moderne et contemporaine. Elle a été directrice de programme au Collège international de philosophie (ICPh) de 2001 à 2007. Avant d'enseigner aux États-Unis, Paola Marrati a occupé une chaire de philosophie de l'art et de la culture à l'Université d'Amsterdam. Ses recherches portent sur la philosophie française contemporaine, en particulier Jacques Derrida et Gilles Deleuze, la philosophie américaine, en particulier les questions morales et politiques dans la philosophie de Cavell, les études cinématographiques et les études de genre. Elle est notamment l'auteure de : La genèse et la trace. Derrida lecteur de Husserl et Heidegger (Kluwer, 1998), Gilles Deleuze, cinéma et philosophie (PUF, 2003) et Gilles Deleuze. Cinema and Philosophy (Johns Hopkins University Press, 2008). Elle a édité Understanding Cavell, Understanding Modernism (Bloomsbury Press, à paraître en décembre 2021). 